\title{
Impact of Project Management Maturity on Service Delivery of Rural Electrification Project in Bugesera District, Rwanda
}

\author{
Aurore BANA SINZI ${ }^{1}$, Professor Edwin ODHUNO ${ }^{2}$ \\ ${ }^{1}$ School of Business and Economics, Mount Kenya University, \\ Kigali, Rwanda \\ ${ }^{2}$ School of Business and Economics, Mount Kenya University, \\ Kigali, Rwanda \\ DOI: 10.29322/IJSRP.11.10.2021.p11880 \\ http://dx.doi.org/10.29322/IJSRP.11.10.2021.p11880
}

\begin{abstract}
The purpose of this study was to examine the impact of project management maturity on service delivery of the rural electrification project in Bugesera District, Rwanda. This research project centered on the three specific objectives namely; to assess the effect of integration management, cost management and quality management on service delivery in rural electrification project in Bugesera District. The study serves as a guideline for project management experts and stakeholders. Findings would be used to benchmark future projects regarding project management maturity and service delivery. The study is also significant for academic future references in the field of project management maturity and project services delivery. The study reviewed contingency and project management maturity theories. The study used descriptive research design with both qualitative and quantitative approaches. The study's target population was 198 people where 132 respondents comprising project beneficiaries, project staff and management were used as a sample. Questionnaires and interviews were used to collect relevant information. Descriptive and inferential statistics were used to analyze quantitative data while content analysis was used to analyze qualitative data. Results from the first objective show a positive significant relationship between project integration management and service delivery because the score is 289 with a p-value of 0.000 . Results of the second objective indicate that there is a positive significant relationship between cost project management and service delivery because the score is 913 and the p value was 0.000 . Results to the third objective indicate a positive significant relationship between quality management maturity and quality of service because the score was 154 with a $\mathrm{p}$ value of 0.000 . In conclusion, project cost is the main feature for showing project management maturity and its service delivery together with schedule and scope of the project. Project Level Tools are initial efforts of reducing cost adjustments that maintain the project on board for its original scope, cost and schedule targets. Therefore, the study proved a positive relationship between project management maturity, and service delivery in in rural electrification project in Bugesera District because all calculated p- values are less than 0.01 level of significance.
\end{abstract}

Keywords: Project, Project Management, Maturity, Project Maturity, Public Project, Service Delivery

\section{Introduction}

Public organizations have resorted to maturity models to improve service delivery for the last 20 years (Backlund, et al., 2013; (Miles \& Snow, 2014). However, the view of project service delivery has evolved since the birth of maturity models, and taking into account other factors without considering integration management, cost management and quality management. Jugdey and Muller (2014) conducted a study on project maturity model and project performance on a long term impact to the users. However, results of this study indicate that less attention has been given to impact of project management maturity on public organizations' service delivery. While other researchers like Mullay (2014) findings lack clear evidence of the real benefit of the application of the maturity model to practitioners.

However, in Rwanda, the Officer of the Auditor General (2018) discovered immaturity in managing Rural Electrification Projects by EDCL, with 5.6 billion of Rwandan Francs spent without proof due to poor service delivery in terms of on-time service delivery, service delivery cost and low customer retention. This has led the parliament to suggest the prosecution on the cause of this loss (AOG, 2018). Hence, the study sought to examine the impact of project management maturity on public projects' service delivery, using a case of Rural Electrification Project in Bugesera District in Rwanda.

The research objectives were: 
i. To assess the effect of project management maturity on customer satisfaction of Rural Electrification Project in Bugesera District.

ii. To determine the effect of project management maturity on customer retention of Rural Electrification Project in Bugesera District.

iii. To assess the relationship between project management maturity and quality of service delivery with reference to Rural Electrification Project in Bugesera District.

\section{Review of Literature}

Project cost is a main feature in computing project success. Actually, project cost is among the three features around time and scope. A project manager who will yield a superior project or service on time and within budget can be demanded highly (Keith, et al, 2012). Characteristically, at the beginning of planning a project, cost is flexible, but project period is fixed as schedule length is sought. Lean Construction Institute (2014) argues that enhancing cost project scope maturity represents an effort aimed at establishing and improving a systematic approach to project management where project success does not focus on controlling the end results, but rather on enabling an efficient and effective functioning of the system. Therefore, it is very difficult to give a comprehensive grade when evaluating project maturity, especially since poorer results in one area cannot be compensated with better results in another.

If cost-schedule-scope goals cannot be achieved, the only resort is to make changes at the business level of authority, and that requires approval from stakeholders such as project sponsors. Knowing and applying the project level and/or business-level tools of the trade for decreasing cost is an important skillset for any project manager (Agarwal, \& Kalmar, T. (2016).

Benefit is best portrayed as a company's capacity to win budgetary benefit from a particular project. It relies upon the cost salary proportion and is a proportion of task operational productivity. The net benefit, in fact, is the income business closes with subsequent to paying all the immediate costs, for example, generation expenses, and different costs identified with the operational and business exercises (Bushuyev \& Wagner, 2014). They also revealed that project management maturity have affected both the cost of the project and delivery of the service that are conducted by the project which in turn enhanced the operational productivity of the project. Estimation is a noteworthy technique to decide project productivity. The key project parameters like cost, execution and time and so forth are estimated after some time to decide the advantages the task may bring about in future (Chen et al., 2010).

Computing the cost-pay proportion gives an understanding that working costs should not surpass working earnings of the task to guarantee smooth running. The undertaking costs are required to be maintained within proper limits in control to keep up solid project benefit. Additionally, operational effectiveness is firmly connected to gainfulness. Increasingly proficient project create more benefits and subsequently work with higher productivity (Kanthana, 2010). A proficient task keeps running with lower operational costs and utilization of assets however delivers wanted outcomes. The project management maturity is also associated with service deliverance in terms of creating more benefits to increase the project productivity with profitability at the same time.

Project Management Maturity Model allows any organizations to develop strategic management for improving its PM implementation (Chen et al., 2010). Results from earlier studies demonstrate that PMMM can

recognize organization's capabilities as well as providing substantial framework for performance improvement Moreover, the role of PMMM be an important key for organizations to ensure the project success and evaluate the organization's capability towards three crucial issue, there are include on budget and schedule completion and within the scope that meet the requirements (Bushuyev \& Wagner, 2014). Furthermore, organizations with more mature are more competent in organizing projects. Consequently, organizations should steadily enhance the potentialities in ten knowledge areas for obtaining greater maturity stage (Bushuyev \& Wagner, 2014).

Therefore in order to achieve the project goals successfully, the project initiators need to consider three perspectives of the project management methodologies, which may include quality, cost and time (Backlund, et al., 2013). It was evidenced that project success or failure regularly depends on management's ability to handle personnel matters properly throughout the final phase.

Project management maturity, as an organizational asset, is designed to improve the project management effectiveness and performance ((Mullay, 2010). In order to understand the claimed increase in performance, it is necessary to look at the concepts of project performance and organization performance.

According to Hillson, 2017), also indicate that project maturity is synonym to how well condition an organization is to handle its projects. The authors also define project maturity in three (3) different dimensions: 1) action (organizational ability to act and decide), 2) attitude (organizational willingness to act), and 3) knowledge (organizational understanding of the consequences of its actions and attitude (Mullay, 2010).

For an association to prevail at achieving its plans, it must make the correct plans expected to achieve those plans and also put together the assets expected to execute those plans, for example, money and work in the genuine usage of those plans. Hierarchical effectiveness is the potential of the association to update its preparations through the least possible use of objects that enhance project management maturity and quality of service given to the customers to raise their satisfaction level for the success of the project and service deliverance (Mullay, 2010). The maturity level in project management of an organization tells how much thisorganization has already moved towards the search for excellence achievement in the management of its projects (DeToro \& McCabe, 2017).

For instance, the nature of an association's work is frequently needy to some extent on the general training of the district in which that association is based (DeToro \& McCabe (2017). Drazin and Van de Ven (2017) found that the very basic assumptions of an organizational culture itself may restrain the knowledge-transfer processes. They claim that a project orientation, in fact, may restrain knowledge transfer, as it leads to knowledge silos. A case study is used to underline the restraining nature of organizational culture based on Schein's hierarchy. (DeToro \& McCabe, 2017). 
ISSN 2250-3153

The below diagram indicates that there is a relationship between project management maturity as independent variable, service delivery as dependent variable and professional development management as dependent variable. 
Independent Variable

Project Management Maturity
Dependent Variable

Service Delivery in Public Projects

Integration Management

- Effective initiation

- Better Planning

- Effective execution

- Effective Control

Cost Management

- Cost Flexibility

- Balanced scope cost

- Negotiation for cost estimates

- Short length of activities

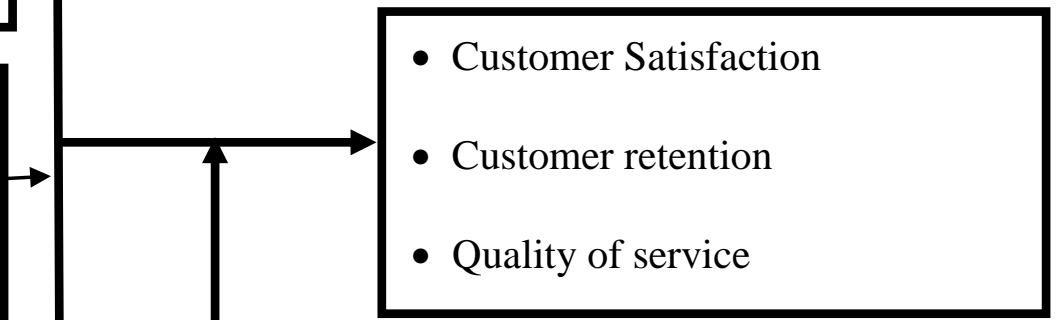

Quality Management

- Competitive power

- Ownership

- Demand/consumption power

- Advertisement strategies

Moderating Variables

- Professional development management

Figure 2. 1 Conceptual Framework

The conceptual framework in Figure 2.1 shows the relationship between the independent and dependent variables. Service delivery depends on project management maturity. However, other variables that can affect service delivery in public organizations include professional development management. The figure 2.1 keep shows that project management maturity as integration management, cost management and procurement management measure a predictor. In this regard, integration management was measured by effective initiation, better planning, effective execution and effective control. The cost management was measured by cost flexibility, balanced scope cost, negotiation for cost estimates and short length of activities. The quality management was measured by competitive power, ownership, and demand/consumption power and advertisement strategies

However, the dependent variable (service delivery) was measured in terms of quality of service, customer service satisfaction and customer retention. The measure of project management maturity as integration management has an effect on customer service satisfaction, quality of service, and customer retention; cost management influences customer retention, quality of service and customer satisfaction; and quality management enhances quality of service, customer service satisfaction and customer retention. However, a factor such as professional development management can also influence the three factors of quality of service, customer service satisfaction and customer retention.

\section{Materials and Methods}

Asika (2010) denotes the research design as a blue print for linking conceptual framework to feasible empirical research. This research used descriptive research survey design and employed a coefficient of correlation to measure effect size-r for each objective with both qualitative and quantitative approaches. The study was conducted in order to collect relevant data. Its purpose This publication is licensed under Creative Commons Attribution CC BY. 
was to find answers to the research questions through the application of the scientific method. It was a systematic and intensive study directed towards a more complete knowledge of the subject study. The primary data were collected via questionnaires and interviews, while secondary data were collected through books, reports and internet. Management as well as all project employees of EDCL under the Projects Implementation Unit including projects administration, projects finance, procurement, projects implementation and projects evaluation teams were approached.

In this regards, the study population included all 198 employees of Rural Electrification Project in Bugesera District under the Projects Implementation Unit and they include projects administration, projects finance, procurement, projects implementation and projects evaluation teams. The employees who participated in this study were only from Rural Electrification Project that is located in Bugesera District, Eastern Province of Rwanda. With the help of Bugesera EDCL management, this project implementation unit has 151 project beneficiaries and 47 project management and staff which total up to 198 people in Rural Electrification Project in Bugesera District (Bugesera EDCL, 2020). The sample size is obtained by using Yamane formula. In this regards, 132 sampled population was selected from 198 target population. The sample size is calculated by the following formula.

$\operatorname{Eq}(1):$

$n=\frac{N}{1+N(e)^{2}}$

When

$\mathrm{n}$ represent sample size $\mathrm{N}$ represents population size $\mathrm{N}$ represent margin error which is equal to 5\% (0.05)

When the Yamane formula is used in this case, the researcher obtains the sample size of 142. This technique is used by the researcher to obtain the sampled population. $n=198 / 1+198(0.05)^{2} ; n=198 / 1+0.495 ; n=198 / 1.495 ; n=148$.

This research mainly used questionnaire and interview guide as instruments in gathering information. Interview was used to collected information from key informants. The study used interview guide with open-ended questions to the respondents to facilitate the respondents to give detailed information during actual data collection period.

\section{Results and Discussion}

\subsection{The influence of Integration Management on Service Delivery of Rural Electrification Project in Bugesera District of Rwanda}

The findings presented in this section are based on the cost of cutting hair which has reduced in rural electrification project, the cost of molding has reduced in rural electrification, the cost of charging phones has reduced in rural electrification project and shortening length of activities is the best way to ensure the quality of service delivery in rural electrification project in Bugesera District, Rwanda.

Correlation between integration management and service delivery

\begin{tabular}{|c|c|c|c|c|}
\hline & & $\begin{array}{l}\text { Customer } \\
\text { satisfaction }\end{array}$ & service Quality of service & Customer retention \\
\hline \multirow{3}{*}{$\begin{array}{l}\text { Integration } \\
\text { management }\end{array}$} & Pearson Correlation & $.770^{* * *}$ & $.910^{* * *}$ & $.801^{* * *}$ \\
\hline & Sig. (2-tailed) & .000 & .000 & .000 \\
\hline & $\mathrm{N}$ & 132 & 132 & 132 \\
\hline
\end{tabular}

**. Correlation is significant at the 0.01 level (2-tailed).

The findings prove that there is a relationship between integration management and customer satisfaction ( $\mathrm{p}=.770$ and $\mathrm{sig}=.000)$, between integration management and quality of service $(\mathrm{p}=.910$ and sig=.000), between integration management and customer retention $(\mathrm{p}=.801$ and $\mathrm{sig}=.000)$ because all calculated $\mathrm{p}$ - values are less than 0.01 level of significance. Hence, there is a positive and significant relationship between predictors of project integration management and service delivery in rural electrification project

District.

\subsection{Effect of Project Cost Management on Service Delivery within Rural Electrification Project in Bugesera District}

The second objective analyzed the effect of project cost management on service delivery of rural electrification project in Bugesera District. Cost management strategies adopted in rural electrification project was measured using fixed period, a balanced scope-cost, negotiation with service providers, and a short length of activities. 
Correlation analysis between predictors of cost management and service delivery in rural electrification project in Bugesera District, Rwanda

\begin{tabular}{llrrr}
\hline & & $\begin{array}{c}\text { Customer service } \\
\text { satisfaction }\end{array}$ & Quality of service & Customer retention \\
\hline & $\mathrm{N}$ & 132 & 132 & 132 \\
\multirow{2}{*}{ Cost } & Pearson Correlation & $.990^{* *}$ & $.715^{* *}$ & $.971^{* *}$ \\
management & Sig. (2-tailed) & .000 & .000 & .000 \\
& $\mathrm{~N}$ & 132 & 132 & 132 \\
\hline
\end{tabular}

**. Correlation is significant at the 0.01 level (2-tailed).

The findings in Table 4.7 proves that there is a relationship between cost management and customer satisfaction ( $\mathrm{p}=.761$ and sig=.000), between cost management and quality service ( $\mathrm{p}=.990$ and sig=.000) between cost management and customer retention $(\mathrm{p}=.715$ and $\mathrm{sig}=.000)$ because all calculated $\mathrm{p}$ - values are less than 0.01 level of significance. Hence, there is a positive and significant relationship between predictors of cost management and service delivery in rural electrification project in Bugesera District.

\subsection{Influence of Project Quality Management on Service Quality of Rural electrification project in Bugesera District} The findings analyzed are based on the views of respondents such as project competitive power that affect customer retention of rural electrification project, project ownership affects customer retention of rural electrification project, correspondence enhances employment opportunities in undertaking customer retention, and efficient recording and data management is key to enhance project customer retention in rural electrification project in Bugesera District of Rwanda.

Correlation analysis between predictors of project quality management and service delivery in rural electrification project in Bugesera District, Rwanda

\begin{tabular}{llccc}
\hline & & $\begin{array}{c}\text { Customer service } \\
\text { satisfaction }\end{array}$ & Quality of service & Customer retention \\
\hline \multirow{2}{*}{ Quality } & Pearson Correlation & $.750^{* *}$ & $.933^{* *}$ & $.781^{* *}$ \\
management & Sig. (2-tailed) & .000 & .000 & .000 \\
& $\mathrm{~N}$ & 132 & 132 & 132 \\
\hline
\end{tabular}

**. Correlation is significant at the 0.01 level (2-tailed).

The findings the relationship between quality management and customer satisfaction $(\mathrm{p}=.750$ and sig=.000) between quality management and quality of service $(\mathrm{p}=.933$ and $\mathrm{sig}=.000)$ between quality management and customer retention ( $\mathrm{p}=.781$ and $\mathrm{sig}=.000)$. Hence, there is a positive and significant relationship between predictors of quality management and service delivery in rural electrification project in Bugesera

\section{Discussion}

Results to the first objective have revealed that there is a positive and significant relationship between project integration management and service delivery that is supported by the study of Kanthana (2010) who revealed that project integration management is also associated with service delivery in terms of creating more benefits to increase the project productivity with profitability at the same time.

Results to the second objective have revealed that there is a positive and significant relationship between cost management and service delivery that is supported by the study of Kanthana (2010) who revealed that project cost management is also associated with service delivery in terms of creating more benefits to increase the project productivity with profitability at the same time.

Results to the third objective have revealed that there is a positive and significant relationship between quality management maturity and service delivery that is supported by the study of Kanthana (2010) who revealed that quality management is also associated with service delivery in terms of creating more benefits to increase the project productivity with profitability at the same time.

\section{Conclusions}

In conclusion, most of the researchers in this field of project management maturity and service delivery such as Martz (2017) stated that project cost is the main feature for showing project management maturity and its service delivery together with schedule and scope of the project. Project Level Tools are initial effort of reducing cost administers adjustments that maintain the project on board for its original scope, cost and schedule targets. Other researchers like Backlund, et al., (2013); and DeToro \& McCabe, (2017) asserted that customer retention and customer satisfaction indicate how far the project management maturity have reached in profit making projects because they are also the primary indicators of project productivity.

Nature of the project management may be the most powerful factor that influences project management maturity and proficiency since it is the project management that picks how to actualize vital plans including choosing what strategies and assets to use, and 
guiding representatives so as to take advantage of their work that in turn influences service delivery of the project (DeToro \& McCabe, 2017).

Therefore, the findings of the study prove that there is a relationship between integration management and customer retention $(\mathrm{p}=.801$ and $\mathrm{sig}=.000)$ between cost management and quality management $(\mathrm{p}=.761$ and sig=.000), between cost management and customer retention $(\mathrm{p}=.990$ and $\mathrm{sig}=.000)$ between cost management and quality of service $(\mathrm{p}=.715$ and sig=.000) between cost management and customer retention $(\mathrm{p}=.971$ and $\mathrm{sig}=.000)$ between quality management and customer retention $(\mathrm{p}=.750$ and sig=.000) between quality management and quality of service ( $\mathrm{p}=.933$ and sig=.000) between quality management and customer retention $(\mathrm{p}=.781$ and $\mathrm{sig}=.000)$ because all calculated $\mathrm{p}$ - values are less than 0.01 level of significance. Hence, there is a relationship between predictors of project management maturity and service delivery in rural electrification project in Bugesera District.

The study recommends, project beneficiaries to pay on time the service that they are given so that the project keeps running and mature. The beneficiaries are also encouraged to ensure safety and security of the project material and equipment that held the project to deliver service to project beneficiaries in rural areas of Bugesera. The management particularly should monitor and closely supervise the activities of general staff because they are the engines of the project management maturity in terms of quality of the service delivered in rural electrification project. The government should put more effort in auditing the government funded projects to ensure that they are not lagging behind compared to private owned projects as the government invests a lot of money in them.

\section{Acknowledgments}

I wish to acknowledge Prof. Edwin Odhuno for his contribution to this work from the beginning up to it's the completion. I also wish to extend my acknowledgement to the Mount Kenya University, Gasabo District authorities for their support and collaborative in term of data collection. 


\section{Reference}

Agarwal, S.A. and Kalmar, T. (2016). Sustainability in Projects Management: Eight Principles in Practice. Jan. 2016.

Asika, N. (2010). Research Methodology in the Behavioral Sciences. Ikeja: Longman

Backlund, F., Butler, M. \& Erik, S. (2013). Project Management Maturity Models - A Critical Review. Journal of Social and Behavioral Sciences, 119 (2), 11-19. DOI: 10.1016/j.sbspro.2014.03.094

Bugesera EDCL. (2020). Trends in Key Agricultural and Rural Development Indicators in Rwanda. MINAGRI, July 2012.

Bushuyev, S.D. \& Wagner, F. R. (2014). IPMA Delta and IPMA Organizational

Chen Choi-Fitzpatrick, J. (2010). A Resource Guide for Enhancing Potential for Sustainable Impact: Food and Nutrition Security. Project Concern International.

DeToro, I., \& McCabe, T. (2017). How to stay flexible and elude fads. Quality Progress.

Drazin, J. S. \& Van de Ven, N. (2015). Project risk management practices: the organizational maturity influence. International Journal on Managing Project Business. 11 (2), 6-7.

Hillson, DA. (2017). Towards a risk maturity model. International Journal of Project Business Risk Management. 7 (4), 11-13.

Jugdey,M\& Muller, M.C. (2014). The production administrative structure: A paradigm for strategic fit. Academy of Management.

Kanthana, D. (2018). The Effects of Cost Management Quality on the Effectiveness of Internal Control and Reliable DecisionMaking: Evidence from Thai Industrial Firms. Advances in Social Science, Education and Humanities Research, 211 (16), $1-10$.

Keith, M., Chris H., \& Daniel T. (2012). Guidebook for Selecting Project Delivery Methods and Alternative Contracting Strategies Technical Memorandum; University of Colorado Boulder, Colorado.

Lean Construction Institute (2014). Where tradition meets public sector innovation: A Rwandan case study for results-based approaches. Third World Quarterly, 40(7)

Martz, W. (2017). Evaluating Organizational Performance: Rational, Natural, and Open System Models. American Journal of Evaluation. 3 (6), 7-9.

Miles, R. E., \& Snow, C. C. (2014). Fit, failure and the hall of fame. California Management Review.

Mullaly, M. (2014). If maturity is the answer, then exactly what was the question? International Journal of Project Management Business. 2 (4), 11-13.

Mullaly, M. E. \& Thomas, J. (2010). Re-thinking project management maturity: perspectives gained from explorations of fit and value, Newtown Square, PA: Project Management Institute.

Office of Auditor General. (2018). Rural Electrification Projects report. Kigali, Rwanda 